\title{
电力工程 EPC 总承包项目造价管理措施分析
}

\section{Analysis on Cost Management Measures of Power Engineering EPC General \\ Contracting Project}

\author{
谢正连 \\ Zhenglian Xie \\ 中煤科工重庆设计研究院(集团)有限公司 中国·重庆 400016
}

Chongqing Design and Research Institute (Group) Co. Ltd., Chongqing, 400016, China

摘 要: EPC 指的是工程总承包模式, 将其应用在电力工程的造价管理工作中, 提高造价管理水平。基于此, 论文就电力工程 EPC 总承包模式的特点以及电力工程 EPC 总承包项目造价管理措施方面进行分析, 希望提高电力工程的整体造价管理水平, 促进中国电力工程行业的发展。

\begin{abstract}
EPC refers to the engineering-procurement-construction mode, which is applied in the cost management of power engineering to improve the level of cost management. Based on this, the paper analyzes the characteristics of EPC general contracting mode of power engineering and cost management measures of EPC general contracting project of power engineering, hoping to improve the overall cost management level of power engineering and promote the development of China's power engineering industry.
\end{abstract}

关键词: 电力工程; 总承包项目; 造价管理;措施

Keywords : power engineering; general contracting project; cost management; measures

DOI : $10.36012 /$ peti.v2i3.2086

\section{1 引言}

电力工程总承包项目是中国基础设施建设中的重要组 成内容,其在实际的建设过程中, 具有规模较大且资金及人 员等方面投入较多的特点。另外, 电力工程总承包项目的建 设周期也较长,无形中也增加了电力工程成本管理工作的难 度。为此, 电力工程单位需要结合电力工程的实际情况, 充分 发挥 EPC 总承包造价管理模式的作用, 优化管理流程, 提高 造价管理效果。

\section{2 电力工程 EPC 总承包模式的特点}

电力工程项目的建设周期较长, 建设规模较大, 通过实 行 EPC 总承包模式, 可以实现工程设计、采购以及施工的一 体化, 在很大程度上也有利于管理人员进行电力工程成本控 制, 保证电力工程的建设质量。另外, 在 EPC 总承包模式下, 总承包单位可以在电力工程设计阶段对工程项目进行采购
和施工计划的制订，实现各个工程阶段的相互衔接和交叉, 以此来提高电力工程的建设效率, 缩短工程施工周期, 减少 资金投入[1]。

在电力工程 $\mathrm{EPC}$ 总承包模式下, 总承包单位属于电力 工程建设过程中的风险主体。当前, 中国市场复杂多变,特别 是电力工程项目的建设涉及的专业也较为广泛, 具有较高的 社会影响力。因此, 总承包单位在进行电力工程全过程的成 本管理时, 管理风险也较大, 需要总承包单位进行系统的动 态管理, 不断降低电力工程总承包单位的成本管理风险, 提 高工程社会效益 ${ }^{[2]}$ 。

\section{3 电力工程 EPC 总承包项目造价管理措施}

\section{1 加强对造价人员的培养, 提高其综合素养}

$\mathrm{EPC}$ 总承包项目造价管理模式在实际应用的过程中, 对 造价管理人员的专业水平和业务能力提出了更高的要求, 为 
此, 造价管理人员需要加强学习, 工程单位也需要加强对管 理人员的培训,具体培训涉及社会、市场、金融以及经济等各 个领域,使其可以综合应用造价理论知识, 对市场的发展趋 势进行准确的判断。另外, 电力工程单位还需要加强造价管 理人员对定额、标准、政策文件、信息智能化工具软件的学习 掌握, 加强造价管理人员对设计图纸的解读能力, 提高对现 场施工工序及工艺流程熟知度, 实现科学有效的电力工程造 价管理。除此之外, 电力工程单位还需要完善相关的激励政 策,激发造价管理人员的自我完善的积极性, 最终提高造价 管理人员的综合素养。

\section{2 加强电力工程的设计工作}

电力工程的设计阶段是实现技术和经济统一和对立的 初步环节, 同时也是关键环节。根据相关调查资料显示, 有 70\% 80\%的电力工程项目造价是在设计阶段就确定的, 因 此, 设计阶段的电力工程造价管理水平直接关系着电力工程 整体的造价管理质量。项目设计阶段要加强基础资料的收集 和现场勘测, 结合工程实际情形, 因地制宜, 优化项目布置, 对项目进行多方案比选和技术经济论证, 选择技术先进、经 济合理、安全可靠的设计方案。同时,采用先进的技术软件工 具, 精准核算项目技术参数, 合理配置设备选型, 从而优化项 目的整体造价。电力企业需要不断优化项目设计阶段的造价 管理, 从根本上实现对工程造价的控制。

\section{3 加强电力项目 EPC 采购阶段的造价管理}

电力工程在实际的建设过程中, 所投入的工程项目设 备、设施都较多, 投资额较大, 在电力工程 EPC 总承包项目 造价管理模式下, 电力企业需要加强电力项目 EPC 采购阶 段的造价管理。第一,单位需要建立完善的设备、原材料采购 制度,并注意编制完善的价格档案、供应商评价体系、供应商 档案以及价格评价体系, 为电力工程材料和设备采购奠定完 善的制度支持; 第二, 单位需要加强对供应商的分析, 具体需 要了解供应商的生产能力、资金情况、信誉情况、项目建设情 况等各个方面的内容, 建立相应的供应商管理系统, 定期或 不定期地对系统中的供应商进行评价, 尽量和信誉较好的供
应商和分包商进行合作关系。

\section{4 加强对工程施工阶段的造价管理}

电力工程单位还需要加强对工程施工阶段的造价管理, 避免因为施工环节管理不当, 增加电力工程的施工成本, 具 体可以从以下 4 个方面人手:第一,单位需要加强对施工人 员的培训, 不断提高施工人员的专业水平和造价意识,使其 在实际的施工阶段做好资金使用计划,施工过程中做好成本 风险预测和成本管控, 科学进行电力工程造价控制; 第二, 单 位需要加强对电力工程造价管理的动态监督, 对工程设计变 更以及现场签证情况进行严格控制; 第三, 电力工程的设计人 员也需要深人施工现场, 对工程的施工过程进行跟进, 及时发 现和设计方案不符的施工操作, 指导施工人员进行处理 ${ }^{[3]}$; 第 四, 采用流水施工, 合理配置人力、物力、财力和施工机械, 统 筹安排, 加强各项工序间的衔接, 提高资源利用效率, 从而提 高项目的整体效益。

\section{5 加强对新技术、新材料、新工艺的研发实践}

加强技术创新, 电力工程单位内部设立技术创新小组, 鼓励研发实用新技术、新材料、新工艺,在保证工期质量的前 提条件下,推行技术革新, 加快技术步伐; 为保护环境、节约 占地、优化资源配置等科学举措践履笃行。

\section{4 结语}

综上所述, 电力工程的建设和管理直接关系着当地的经 济和社会发展,通过应用 EPC 总承包模式进行造价管理,可 以有效地完善造价管理流程,提高管理效益,因此,具有较高 的应用价值。

\section{参考文献}

[1] 周康. 电力企业 EPC 总承包项目造价管理探讨[J].价值工程, 2018,37(24):1-2.

[2] 李娟.电力企业 EPC 总承包项目造价管理探讨[J].名城绘,2018 (12):609.

[3] 刘文轩.EPC 模式下电网项目造价控制策略[J]. 大科技,2018 (36):228-229. 